\section{THE MODIFIED FONTAN OPERATION}

\section{An analysis of risk factors for early postoperative death or takedown in 702 consecutive patients from one institution}

To better understand risk factors associated with early postoperative death or failure, we reviewed our entire experience with 702 consecutive patients who had the modified Fontan operation at the Mayo Clinic between October 1973 and December 1989. The event rate for takedown of repair or death during the initial hospitalization or within 30 days of the operation was $14.8 \%$ (successful takedown of the repair, $n=6$; death, $n=98$ ). To identify variables associated with early death or Fontan takedown, we analyzed 33 clinical and hemodynamic variables in a univariate and multivariate manner. On the basis of a stepwise logistic discriminant analysis, patients who were younger and operated on before 1980 with a higher preoperative pulmonary artery mean pressure, asplenia, higher intraoperative (after Fontan operation) right atrial pressure, longer aortic crossclamp time, and pulmonary artery ligation were more likely to have the outcome event of interest $(p$ values $<0.05$ ). A new variable, corrected pulmonary artery pressure (that is, mean preoperative pulmonary artery pressure divided by the ratio of pulmonary to systemic flow if the ratio of pulmonary to systemic flow is greater than 1.0), was significantly associated with the outcome event univariately $(p=0.002)$, but was no more predictive than the preoperative pulmonary artery mean pressure. Variables less predictive of the outcome event in this analysis included multiple prior operations, polysplenia syndrome, complex anatomy other than asplenia syndrome, and systemic atrioventricular valve regurgitation. These results represent the largest single-institution review of the Fontan operation and suggest that some anatomic and hemodynamic variables previously predictive of poor early outcome have been nullified by current operative methods. (J ThORAC CARDIOVASC SuRg 1995;109:1237-43)

Christopher J. Knott-Craig, MD, ${ }^{*}$ Gordon K. Danielson, MD, ${ }^{a}$ Hartzell V. Schaff, MD, ${ }^{\text {a }}$ Francisco J. Puga, MD, ${ }^{a}$ Amy L. Weaver, MS, ${ }^{b}$ and David D. Driscoll, MD, ${ }^{\mathrm{c}}$

Rochester, Minn.
Qince the first successful Fontan operation for $\checkmark$ tricuspid atresia was reported in $1971,{ }^{1}$ numerous modifications have been proposed as definitive palliation for an increasing variety of complex cyanotic congenital heart defects with a functional single ventricle. ${ }^{2-19}$ More recently, surgical modifications have focused on staging the separation of systemic and pulmonary circulations ${ }^{9-13}$ in an attempt to reduce the early mortality and morbidity

From the Section of Thoracic and Cardiovascular Surgery, ${ }^{\mathbf{a}}$ the Department of Cardiology, ${ }^{\mathrm{C}}$ and the Section of Biostatistics, Mayo Clinic and Mayo Foundation, Rochester, Minn.

*Visiting Professor in Section of Thoracic and Cardiovascular Surgery: sponsor, Gordon K. Danielson, MD. Recipient of the Evarts A. Graham Memorial Traveling Fellowship of the American Association for Thoracic Surgery (1989-1990).

Received for publication March 10, 1994.

Accepted for publication Oct. 24, 1994.

Address for reprints: David D. Driscoll, MD, Mayo Clinic, 200 First St. SW, Rochester, MN 55905.

Copyright $(\mathcal{C} 1995$ by Mosby-Year Book, Inc.

$0022-5223 / 95 \$ 3.00+0 \quad \mathbf{1 2 / 1 / 6 1 4 8 4}$ associated with the modified Fontan operation in patients with higher risk factors.

As experience was gained with the modified Fontan operation at the Mayo Clinic and more patients with complex cyanotic heart disease requiring a one-ventricle repair were referred, our selection criteria were broadened to accommodate these high-risk patients, often with encouraging early results. ${ }^{20-24}$ However, apart from modifications for specific technical difficulties, ${ }^{3,4,6,25}$ the operation has remained essentially unchanged throughout the years, allowing this analysis of risk factors for early failure to be undertaken with little influence of surgical variation.

\section{Patients and methods}

Study group. Since the first operation at the Mayo Clinic in October 1973 and as of the end of 1989, 702. consecutive patients had the modified Fontan operation. These 702 patients form the basis of this review. All but 8 of these 702 patients known to be alive at the date of the most recent follow-up had more than 30 days of postoperative follow-up. 
The age at operation ranged from 8 months to 42 years, and the median age was 9 years. Forty percent of the patients were female. The primary cardiac defect was tricuspid atresia in $203(28.9 \%)$, double-inlet ventricle in $226(32.2 \%)$, and complex cardiac defects in 273 (38.9\%).

Surgical technique. The surgical techniques have been described fully elsewhere ${ }^{15,18,21}$ and may be summarized as follows: the operation usually was done with the use of deep hypothermia $\left(20^{\circ}\right.$ to $\left.25^{\circ} \mathrm{C}\right)$ facilitated by periods of low-flow perfusion $(0.5$ to $1.5 \mathrm{~L} / \mathrm{min}$ per square meter) or circulatory arrest as necessary. Intermittent cold blood or crystalloid cardioplegia and topical hypothermia were used for myocardial protection. Direct atriopulmonary connection was the preferred anastomosis for tricuspid atresia and double-inlet left ventricle. In most patients with univentricular heart, the systemic and pulmonary venous drainage was partitioned in such a way that the coronary sinus drained into the pulmonary venous side of the atrial baffle, but no special techniques were used to achieve this if the anatomy was unfavorable. Partial Fontan techniques such as the fenestrated Fontan procedure, ${ }^{12,13,26}$ adjustable atrial septal defect Fontan procedure, ${ }^{10,11,27}$ hemi-Fontan or bidirectional cavopulmonary shunt, or both the latter procedures together ${ }^{9,28,29}$ were not used, and variations of the total cavopulmonary connection or lateral atrial tunnel repair ${ }^{3,5,30}$ were only used for anomalies of systemic or pulmonary venous drainage, as previously described.

Outcome event. The outcome event for this study was defined as takedown of the repair or death during the initial hospitalization or within 30 days of the operation.

Statistical analysis. Associations between the outcome event and 33 clinical and hemodynamic variables (Tables I and II) were analyzed univariately by the $\chi^{2}$ test or Fisher's exact test, or both, for dichotomous variables and the Wilcoxon rank-sum test for continuous and ordinal variables. A stepwise multiple logistic discriminant analysis was used to identify factors jointly associated with the outcome event after the modified Fontan operation. Variables were retained in the multivariate analysis if their $p$ values were less than 0.05 . The odds ratios and corresponding $95 \%$ confidence intervals for each statistically significant variable were then calculated on the basis of the estimated coefficients obtained from the logistic model.

From the final logistic model, an estimated predicted probability of having the outcome event was obtained for each patient. The sensitivity of the model was defined as the proportion of patients who had the event who each had a model-predicted probability higher than a given cutoff value, whereas specificity was the proportion of patients who did not have the event who had modelpredicted probabilities below the cutoff value.

\section{Results}

The mortality rate during the initial hospitalization or within 30 days of the operation was $14.0 \%$ $(n=98)$ and an additional 6 of 16 patients survived takedown of the repair, for a combined event rate of $14.8 \%(n=104)$. This rate has significantly dimin- ished over the years from $26.6 \%$ before 1980 to $13.0 \%$ since $1980(p<0.001)$ (Table III) despite the increased number of high-risk patients currently undergoing operation.

Univariate analysis. Patients who had the outcome event were more likely to have a complex form of functional single ventricle, asplenia, ligation of the pulmonary artery, higher intraoperative right atrial pressure (before and after the Fontan operation) and higher intraoperative left atrial pressure (after the Fontan procedure), higher preoperative and intraoperative (before Fontan procedure) pulmonary artery mean pressure, longer aortic crossclamp time, larger heart size (preoperative cardiothoracic ratio), higher ventricular end-diastolic pressure, and younger age and lower body weight at the time of operation (Tables I and II, $p<0.05$ ). Concomitant repair or replacement of the atrioventricular valve was of marginal significance $(p=$ 0.057 ).

A new variable, "corrected pulmonary artery pressure," was also examined. This is defined as mean pulmonary artery pressure divided by the ratio of pulmonary to systemic flow (Qp/Qs) (if $\mathrm{Qp} / \mathrm{Qs}$ is greater than 1.0) or, if $\mathrm{Qp} / \mathrm{Qs}$ is 1.0 or smaller, mean pulmonary artery pressure divided by unity. Although this was highly significant $(p=0.002)$, it was no more predictive than preoperative pulmonary artery mean pressure and therefore was not included in the multivariate model.

Multivariate analysis. On the basis of a stepwise logistic discriminant analysis, seven variables were identified as associated with the outcome event of interest: year of operation before 1980, presence of asplenia, younger age at operation, higher preoperative pulmonary artery mean pressure, longer aortic crossclamp time, pulmonary artery ligation, and higher intraoperative right atrial pressure (after Fontan procedure) (Table IV). At a specificity of $80 \%$, the sensitivity for this model was $73 \%$.

\section{Discussion}

The Fontan-type repair may be the definitive palliation for a variety of complex cyanotic heart defects. During the past decade, the indications for the modified Fontan operation were extended to patients with more complex lesions ${ }^{2,4-6,15-16,24-25}$ and to patients who fulfilled fewer and fewer of the widely accepted criteria for low-risk operation. ${ }^{7,17-19,21,31}$ Associated with this enthusiasm for the Fontan repair came a better understanding of the hemodynamics and pathophysiologic features of the repair ${ }^{5,26,32-37}$ 
Table I. Univariate relations between dichotomous or ordinal demographic/clinical variables and early postoperative death or takedown

\begin{tabular}{|c|c|c|c|}
\hline \multirow[b]{2}{*}{ Factor (\% missing)* } & \multirow{2}{*}{$\begin{array}{c}\text { No. of } \\
\text { patients }\end{array}$} & \multicolumn{2}{|c|}{$\begin{array}{c}\text { Takedown } \\
\text { and/or } \\
\text { hospital } \\
\text { death }\end{array}$} \\
\hline & & $\%$ & $p$ Value \\
\hline \multicolumn{4}{|l|}{ Gender } \\
\hline Male & 422 & 16 & 0.450 \\
\hline Female & 280 & 14 & \\
\hline \multicolumn{4}{|l|}{ Lesion } \\
\hline Complex & 273 & 19 & 0.012 \\
\hline Other & 429 & 12 & \\
\hline \multicolumn{4}{|l|}{ Polysplenia } \\
\hline Yes & 46 & 22 & 0.171 \\
\hline No & 656 & 14 & \\
\hline \multicolumn{4}{|l|}{ Asplenia } \\
\hline Yes & 46 & 35 & $<0.001$ \\
\hline No & 656 & 13 & \\
\hline \multicolumn{4}{|c|}{$\begin{array}{l}\text { Enlargement of bulbar ven- } \\
\text { tricular foramen }\end{array}$} \\
\hline Yes & 59 & 17 & 0.630 \\
\hline No & 643 & 15 & \\
\hline \multicolumn{4}{|c|}{$\begin{array}{l}\text { Left and/or right pulmonary } \\
\text { artery reconstruction }\end{array}$} \\
\hline Yes & 154 & 14 & 0.834 \\
\hline No & 548 & 15 & \\
\hline \multicolumn{4}{|c|}{$\begin{array}{l}\text { AV valve repair or replace- } \\
\text { ment }\end{array}$} \\
\hline Yes & 66 & 23 & 0.057 \\
\hline No & 636 & 14 & \\
\hline \multicolumn{4}{|l|}{$\begin{array}{l}\text { Preoperative AV valve } \\
\text { insufficiency }\end{array}$} \\
\hline None & 459 & 15 & 0.620 \\
\hline Mild & 152 & 13 & \\
\hline Moderate & 45 & 16 & \\
\hline Severe & 46 & 22 & \\
\hline \multicolumn{4}{|c|}{$\begin{array}{l}\text { Preoperative pulmonary AV } \\
\text { fistula }\end{array}$} \\
\hline Yes & 18 & 17 & 0.740 \\
\hline No & 684 & 14 & \\
\hline \multicolumn{4}{|l|}{$\begin{array}{l}\text { Division of pulmonary } \\
\text { artery }\end{array}$} \\
\hline Yes & 257 & 12 & 0.119 \\
\hline No & 445 & 16 & \\
\hline \multicolumn{4}{|l|}{$\begin{array}{l}\text { Ligation of pulmonary } \\
\text { artery }\end{array}$} \\
\hline Yes & 245 & 20 & 0.005 \\
\hline No & 454 & 12 & \\
\hline \multicolumn{4}{|l|}{ AV valve patch closed } \\
\hline Yes & 228 & 15 & 0.970 \\
\hline No & 466 & 15 & \\
\hline \multicolumn{4}{|l|}{$\begin{array}{l}\text { Preoperative atrial arrhyth- } \\
\text { mia }\end{array}$} \\
\hline Yes & 66 & 12 & 0.518 \\
\hline No & 636 & 15 & \\
\hline \multicolumn{4}{|l|}{ Valved connection } \\
\hline Yes & 52 & 13 & 0.773 \\
\hline No & 650 & 15 & \\
\hline
\end{tabular}

Table I. Cont'd

\begin{tabular}{|c|c|c|c|}
\hline \multirow[b]{2}{*}{ Factor (\% missing) ${ }^{*}$} & \multirow{2}{*}{$\begin{array}{c}\text { No. of } \\
\text { patients }\end{array}$} & \multicolumn{2}{|c|}{$\begin{array}{l}\text { Takedown } \\
\text { and/or } \\
\text { hospital } \\
\text { death }\end{array}$} \\
\hline & & $\%$ & $p$ Value \\
\hline \multicolumn{4}{|l|}{$\begin{array}{c}\text { Pulmonary arteriolar resis- } \\
\text { tance index }(39 \%)\end{array}$} \\
\hline$<2$ & 297 & 14 & 0.238 \\
\hline $2-4$ & 117 & 16 & \\
\hline $5+$ & 13 & 31 & \\
\hline \multicolumn{4}{|c|}{ NYHA functional class (32\%) } \\
\hline I & 8 & 13 & 0.121 \\
\hline II & 252 & 15 & \\
\hline III & 207 & 20 & \\
\hline IV & 9 & 22 & \\
\hline \multicolumn{4}{|c|}{$\begin{array}{l}\text { Intraoperative (after Fontan) } \\
\text { RA pressure }\end{array}$} \\
\hline$>20$ & 110 & 37 & $<0.001$ \\
\hline$\leq 20$ & 574 & 9 & \\
\hline \multicolumn{4}{|c|}{$\begin{array}{l}\text { Intraoperative (after Fontan) } \\
\text { LA pressure }\end{array}$} \\
\hline$>10$ & 273 & 19 & 0.001 \\
\hline$\leq 10$ & 387 & 10 & \\
\hline \multicolumn{4}{|l|}{$\begin{array}{l}\text { Ventricular end-diastolic } \\
\text { pressure }(15 \%)\end{array}$} \\
\hline$>15$ & 158 & 16 & 0.664 \\
\hline$\leq 15$ & 440 & 15 & \\
\hline \multicolumn{4}{|l|}{ Ejection fraction $(52 \%)$} \\
\hline$\leq 50$ & 104 & 14 & 0.347 \\
\hline$>50$ & 231 & 11 & \\
\hline \multicolumn{4}{|l|}{ Age (yr) } \\
\hline$<4$ & 84 & 25 & 0.005 \\
\hline$\geq 4$ & 618 & 13 & \\
\hline \multicolumn{4}{|l|}{ Weight (kg) } \\
\hline$\leq 15$ & 131 & 24 & 0.001 \\
\hline$>15$ & 567 & 13 & \\
\hline
\end{tabular}

All variables are preoperative measurements except for intraoperative right and left atrial pressure measurements. $A V$, Atrioventricular; $N Y H A$, New York Heart Association; $R A$, right atrial; $L A$, left atrial.

*Percentage of patients with missing data.

and improved perioperative management, all of which translated into better early results. As experience was gained, newer surgical innovations became available to deal with the most complex of lesions, ${ }^{2-5,8-9,15,30,38}$ to reduce the frustrating early morbidity related to the postoperative accumulation of persistent or recurrent serous fluids, $5,10-11,26,39-40$ to improve the hemodynamics by possibly streamlining the systemic venous channels, ${ }^{5,30}$ and to support the patient during fluctuations in cardiac output and pulmonary vascular resistance.

More recently, we $\mathrm{e}^{21,23}$ and others ${ }^{10,41-42}$ have cautioned against the application of the Fontan principle to patients who were less than ideal candidates for the operation, indicating that not only 
Table II. Univariate relations between continuous demographic/clinical variables and early postoperative death or takedown

\begin{tabular}{|c|c|c|c|c|c|c|c|c|}
\hline \multirow[b]{3}{*}{ Factor } & \multirow{3}{*}{$\begin{array}{l}\text { Overall } \\
\text { percent } \\
\text { missing }\end{array}$} & \multicolumn{6}{|c|}{ Early postoperative death or takedown } & \multirow[b]{3}{*}{ p Value } \\
\hline & & \multicolumn{3}{|c|}{ No $(n=598)$} & \multicolumn{3}{|c|}{ Yes $(n=104)$} & \\
\hline & & Median & Mean & Range & Median & Mean & Range & \\
\hline Age (yr) & 0 & 9.0 & 11.0 & $0.66-42.0$ & 6.0 & 8.0 & $0.66-29.0$ & $<0.001$ \\
\hline No. of prior procedures & 0 & 1 & 1.3 & $0-6$ & 1 & 1.5 & $0-7$ & 0.181 \\
\hline $\begin{array}{l}\text { Intraoperative (before Fontan) RA pressure } \\
(\mathrm{mm} \mathrm{Hg})\end{array}$ & 31 & 8 & 8.5 & $1-25$ & 9 & 9.9 & $2-23$ & 0.046 \\
\hline $\begin{array}{l}\text { Intraoperative (before Fontan) PA mean } \\
\text { pressure (mm Hg) }\end{array}$ & 47 & 13 & 14.2 & $3-53$ & 16 & 18.1 & $5-58$ & 0.002 \\
\hline $\begin{array}{l}\text { Intraoperative (after Fontan) RA pressure } \\
(\mathrm{mm} \mathrm{Hg})\end{array}$ & 3 & 18 & 17.7 & $8-30$ & 20 & 20.2 & $9-34$ & $<0.001$ \\
\hline $\begin{array}{l}\text { Intraoperative (after Fontan) LA pressure } \\
\text { (mm Hg) }\end{array}$ & 6 & 10 & 9.9 & $2-23$ & 11 & 11.5 & $3-25$ & $<0.001$ \\
\hline Crossclamp time (min) & 8 & 68 & 71.1 & 4-199 & 76 & 79.9 & $5-189$ & 0.026 \\
\hline Preoperative CT ratio & 10 & 0.55 & 0.55 & $0.29-0.81$ & 0.59 & 0.58 & $0.42-0.82$ & 0.003 \\
\hline Preoperative PA mean pressure (mm $\mathrm{Hg}$ ) & 15 & 16 & 18.0 & $2-73$ & 19.5 & 22.2 & $8-58$ & $<0.001$ \\
\hline Preoperative $\mathrm{Qp} / \mathrm{Qs}$ & 33 & 1.18 & 1.56 & $0.15-9.00$ & 1.34 & 1.57 & $0.22-6.50$ & 0.921 \\
\hline $\begin{array}{l}\text { Pulmonary arteriolar resistance index } \\
\left(\mathrm{mm} \mathrm{Hg} / \mathrm{L} / \mathrm{min} \cdot \mathrm{m}^{2}\right)\end{array}$ & 39 & 1.4 & 1.6 & $0.1-5.6$ & 1.5 & 1.8 & $0.2-4.5$ & 0.247 \\
\hline $\begin{array}{l}\text { Total pulmonary resistance }(\mathrm{mm} \mathrm{Hg} / \mathrm{L} / \\
\left.\min \cdot \mathrm{m}^{2}\right)\end{array}$ & 43 & 3.7 & 4.1 & $0.5-11.6$ & 3.8 & 4.4 & $0.8-14.0$ & 0.288 \\
\hline Ventricular end-diastolic pressure $(\mathrm{mm} \mathrm{Hg})$ & 15 & 12 & 12.7 & $5-32$ & 14 & 14.0 & $5-34$ & 0.023 \\
\hline Preoperative ejection fraction (\%) & 52 & 57 & 55.7 & $30-82$ & 55.5 & 56.0 & $34-78$ & 0.852 \\
\hline Weight $(\mathrm{kg})$ & 1 & 26.2 & 31.8 & $5.9-99.0$ & 18.5 & 24.0 & $5.7-79.5$ & $<0.001$ \\
\hline PA mean pressure/(Qp/Qs) ${ }^{*}$ & 37 & 12.0 & 12.6 & $0.9-34.8$ & 13.0 & 14.9 & $2.4-30.4$ & 0.002 \\
\hline
\end{tabular}

$R A$, right atrial; $P A$, pulmonary artery; $L A$, left atrial; $C T$, cardiothoracic.

*If $\mathrm{Qp} / \mathrm{Qs}>1$ or pulmonary artery mean pressure/1; if $\mathrm{Qp} / \mathrm{Qs} \leq 1$.

Table III. Distribution of early postoperative death or takedown by year of operation

\begin{tabular}{|c|c|c|c|}
\hline \multirow{2}{*}{$\begin{array}{l}\text { Year of } \\
\text { operation }\end{array}$} & \multirow{2}{*}{$\begin{array}{l}\text { No. of } \\
\text { patients }\end{array}$} & \multicolumn{2}{|c|}{$\begin{array}{l}\text { Takedown and/ } \\
\text { or hospital death }\end{array}$} \\
\hline & & No. & $\%$ \\
\hline 1973 & 1 & 0 & $\ldots$ \\
\hline 1974 & 3 & 2 & 67 \\
\hline 1975 & 4 & 1 & 25 \\
\hline 1976 & 5 & 1 & 20 \\
\hline 1977 & 10 & 2 & 20 \\
\hline 1978 & 19 & 2 & 11 \\
\hline 1979 & 52 & 17 & 33 \\
\hline Subtotal & 94 & 25 & 27 \\
\hline 1980 & 41 & 9 & 22 \\
\hline 1981 & 48 & 9 & 19 \\
\hline 1982 & 60 & 11 & 18 \\
\hline 1983 & 50 & 5 & 10 \\
\hline 1984 & 59 & 6 & 10 \\
\hline 1985 & 70 & 9 & 13 \\
\hline 1986 & 74 & 11 & 15 \\
\hline 1987 & 66 & 8 & 12 \\
\hline 1988 & 73 & 3 & 4 \\
\hline 1989 & 67 & 8 & 12 \\
\hline Subtotal & 608 & 79 & 13 \\
\hline Total & 702 & 104 & 15 \\
\hline
\end{tabular}

was the attrition rate high during the first 6 months after operation, but also that late complications developed in a significant proportion of patients after the repair, including arrhythmias, ${ }^{23-43}$ proteinlosing enteropathy, ${ }^{44-46}$ and progressive cardiac failure and death. ${ }^{20,23,41-42}$ Recent modifications such as the bidirectional Glenn anastomosis, fenestrated Fontan procedure, and adjustable atrial-septal defect after the Fontan operation may reduce significantly the perioperative morbidity and mortality. Whether this will translate into better long-term survival is unfortunately still unknown.

In the long term there may be advantages to earlier operations such as minimizing the deleterious effects of ventricular hypertrophy, chronic volume overload, and deteriorating cardiac function. ${ }^{17,41,42}$ However, in our experience, which spans 16 years and in which two surgeons (G. K. D. and F. J. P.) each performed more than 300 modified Fontan operations on patients whose ages ranged from 8 months to 42 years, patients younger than 4 years still have a greater risk of dying or having the repair taken down after operation than do older patients. The discrepancy of this risk, 
Table IV. Summary of logistic discriminant analysis

\begin{tabular}{lcccc}
\hline \multicolumn{1}{c}{ Variable } & $\begin{array}{c}\text { Estimated } \\
\text { beta } \\
\text { coefficient }\end{array}$ & Delta & Odds ratio* (95\% CI) & $p$ Value \\
\hline Intraoperative (after Fontan) RA pressure & 0.235 & 2 & $1.60(1.31,1.94)$ & $<0.001$ \\
Operation before 1980 (yes vs. no) & 1.649 & 1 & $5.20(2.45,11.04)$ & $<0.001$ \\
Age (yr) & -0.096 & -3 & $1.33(1.14,1.57)$ & $<0.001$ \\
Preoperative PA mean pressure & 0.060 & 3 & $1.20(1.10,1.30)$ & $<0.001$ \\
Asplenia (yes vs. no) & 1.080 & 1 & $2.94(1.17,7.40)$ & 0.022 \\
Crossclamp time (min) & 0.011 & 8 & $1.09(1.01,1.18)$ & 0.024 \\
Ligation of PA (yes vs. no) & 0.605 & 1 & $1.83(1.04,3.22)$ & 0.036 \\
\hline
\end{tabular}

$C l$, confidence interval; $R A$, right atrial; $P A$, pulmonary artery.

*Estimated odds of having an event per delta unit change in the value of each variable.

however, has decreased with more recent year of operation. Most surgeons currently think that the optimal age for the modified Fontan operation in uncomplicated cases should be 2 to 4 years. $7,17-19,47$ Our data may be influenced adversely by the disproportionate number of patients with many risk factors (in addition to younger age). Indeed, we have reported that in patients at low risk the mortality for the 2- to 4-year-old patients is no different from that of older patients. ${ }^{18}$

However, it is important to emphasize that a major limitation of a retrospective study such as this one is the unavailability of complete data on all patients. For example, a measurement of preoperative ejection fraction was unavailable for $52 \%$ of the patients in this study. In addition, a clinical selection process may exclude patients with presumed adverse risk factors from the cohort. Both of these factors will prevent the identification of important predictive variables.

Although higher pulmonary arteriolar resistance is unquestionably an important risk factor, we could not identify it as an independent variable in this analysis. This may reflect both the narrow range within which patients are accepted for operation and the high proportion $( \pm 40 \%)$ of patients in whom data for this variable were missing. It is reasonable, however, to assume that both higher preoperative pulmonary artery mean pressure and higher postoperative right atrial pressure (both highly significant determinants of an event in this analysis) reflect elevated pulmonary vascular resistance.

We were somewhat surprised to find that the new variable corrected pulmonary artery pressure was not more predictive of an event than simply the use of the pulmonary artery mean pressure. Again, the $37 \%$ missing data may have diminished the statisti- cal significance of this new concept. Motivation for the development of this variable derived from the clinical situation in which a patient with a pulmonary artery pressure of, for example, $24 \mathrm{~mm} \mathrm{Hg}$ is evaluated for operation. If the Qp/Qs in this patient is, for example, 2:1 and this is restored to $1: 1$ by the operation, then the pulmonary artery pressure may be expected to be reduced to $12 \mathrm{~mm} \mathrm{Hg} \mathrm{(24/2)} \mathrm{after}$ operation.

The need for reconstruction of the pulmonary arteries, significant systemic atrioventricular valve regurgitation, and the number of previous operations were not determinants of an event in this study. Because the follow-up period was restricted to hospital discharge or 30 days after operation, we did not assess whether these factors were still predictive of a poor long-term outcome. ${ }^{23}$

Though our results with this subgroup have improved over the years, ${ }^{4}$ the heterotaxia asplenia syndrome remains a significant determinant of an event in this study. This reflects the complex cardiac pathologic features present and the complicated intracardiac baffles necessary to separate the circulations. However, the significance of pulmonary artery ligation as a risk factor is less clear: 502 of the 702 patients in this study had either ligation $(n=$ $245)$ or division $(n=257)$ of the main pulmonary artery, and although division of the main pulmonary artery is not statistically important $(p=0.119)$, ligation of the pulmonary artery was significant both univariately $(p=0.005)$ and multivariately $(p=$ $0.036)$. Whether this is a confounding variable, a positive variable (for example, ligation may occasionally result in some distortion of either the branch pulmonary arteries or even closely related coronary arteries), or a negative variable (for example, not ligating the pulmonary artery and allowing a small amount of prograde flow through a severely 
obstructive pulmonary artery may be beneficial in the short term) is extremely difficult to determine in a retrospective analysis such as this.

From the multivariate analysis it is evident that younger age, higher preoperative pulmonary artery mean pressure, higher postrepair right atrial pressure, early year of operation, presence of asplenia syndrome, longer aortic crossclamp time, and ligation of the pulmonary artery are important determinants of an event in this analysis (Table IV). For this model at a specificity of $80 \%$, the sensitivity was $73 \%$.

One should, however, be cautious when drawing conclusions from this study, because the end point for an event is early postoperative death or Fontan takedown. Although this allows for easy comparison with other studies, a good outcome by this definition does not necessarily reflect a satisfactory overall result, because the attrition rate is known to be higher for the first 6 months after operation. ${ }^{21,41-42}$ This is an important major limitation of an analysis such as this. However, the objective of the study was to relate the risk analysis for early postoperative death or takedown in our patient cohort to that of previous studies to determine whether any risk factors have been nullified by experience and time, both within our practice and relative to other large series.

\section{REFERENCES}

1. Fontan F, Baudet E. Surgical repair of tricuspid atresia. Thorax 1971;26:240-8.

2. Kawashima Y, Kitamura S, Matsuda H, Shimazaki Y, Nakano S, Hirose H. Total cavopulmonary shunt operation in complex cardiac anomalies: a new operation. J THORAC CARDIOVASC SURG 1984;87:74-81.

3. Puga FJ, Chiavarelli M, Hagler DJ. Modifications of the Fontan operation applicable to patients with left atrioventricular valve atresia or single atrioventricular valve. Circulation 1987;76(Suppl):III53-60.

4. Humes RA, Feldt RH, Porter CJ, Julsrud PR, Puga FJ, Danielson GK. The modified Fontan operation for asplenia and polysplenia syndrome. J THORAC CARDIOVASC SURg 1988;96:212-8.

5. de Leval M, Kilner P, Gewillig M, Bull C, McGoon DC. Total cavopulmonary connection: a logical alternative to atriopulmonary connection for complex Fontan operations--experimental studies and early clinical experience. J Thorac Cardiovasc Surg 1988;96:682-95.

6. Russo P, Danielson GK, Puga FJ, McGoon DC, Humes R. Modified Fontan procedure for biventricular hearts with complex forms of double-outlet right ventricle. Circulation 1988;78(Suppl):III20-5.

7. Mayer JE, Helgason H, Jonas RA, et al. Extending the limits for modified Fontan procedures. J THORAC Cardiovasc Surg 1986;92:1021-8.

8. DiDonato R, di Carlo DC, Giannico S, Marcelletti C. Palliation of complex cardiac anomalies with subaortic obstruction: new operative approach. J Am Coll Cardiol 1989;13:406-12.

9. Lamberti JL, Spicer RL, Waldman JD, et al. The bidirectional cavopulmonary shunt. J THORAC CARDIOVASC SURG 1990;100:22-30.

10. Laks H. The partial Fontan procedure: a new concept and its clinical application [Editorial comment]. Circulation 1990;82:1866-7.

11. Laks H, Haas GS, Pearl JM, et al. The use of an adjustable intraatrial communication in patients undergoing the Fontan and definitive right heart procedures [Abstract]. Circulation 1988;78(Suppl):II357.

12. Bridges ND, Lock JE, Castaneda AR. Baffle fenestration with subsequent transcatheter closure: modification of the Fontan operation for patients at increased risk. Circulation 1990;82:1681-9.

13. Mavroudis C, Zales VR, Backer CL, Muster AJ, Latson LA. Fenestrated Fontan with delayed catheter closure: effects of volume loading and baffle fenestration on cardiac index and oxygen delivery. Circulation 1992;86(Suppl):II85-92.

14. Choussat A, Fontan F, Besse P, Vallot F, Chauve A, Bricaud H. Selection criteria for Fontan's procedure. In: Anderson RH, Shinebourne EA, eds. Paediatric cardiology 1977. Edinburgh: Churchill Livingstone, 1978:559-66.

15. King RM, Puga FJ, Danielson GK, Julsrud PR. Extended indications for the modified Fontan procedure in patients with anomalous systemic and pulmonary venous return. In: Doyle EF, Gersony WM, Rashkind WJ, Talner NS, eds. Pediatric cardiology: proceedings of the second World Congress. New York: Springer Verlag, 1986:523-6.

16. Marcelletti C, Mazzera E, Olthof H, et al. Fontan's operation: an expanded horizon. J THORAC CARDIOVASC SURG 1980;80:764-9.

17. Pearl JM, Laks H, Drinkwater DC, Capouya ER, George BL, Williams RG. Modified Fontan procedure in patients less than 4 years of age. Circulation 1992;86(Suppl):II102-5.

18. Bartmus DA, Driscoll DJ, Offord KP, et al. The modified Fontan operation for children less than 4 years old. J Am Coll Cardiol 1990;15:429-35.

19. Myers JL, Waldhausen JA, Weber HS, et al. A reconsideration of risk factors for the Fontan operation. Ann Surg 1990;221:738-44.

20. Humes RA, Porter CJ, Mair DD, et al. Intermediate follow-up and predicted survival after the modified Fontan procedure for tricuspid atresia and doubleinlet ventricle. Circulation 1987;76(Suppl):III67-71.

21. Knott-Craig CJ, Julsrud PJ, Schaff HV, Puga FJ, Danielson GK. Pulmonary artery size and clinical 
outcome after the modified Fontan operation. Ann Thorac Surg 1993;55:646-51.

22. Mair DD, Rice JM, Hagler DJ, Puga FJ, McGoon DC, Danielson GK. Outcome of the Fontan procedure in patients with tricuspid atresia. Circulation 1985;72(Suppl):II88-92.

23. Driscoll DJ, Offord KP, Feldt RH, Schaff HV, Puga FJ, Danielson GK. Five- to fifteen-year follow-up after Fontan operation. Circulation 1992;85:469-96.

24. Gale AW, Danielson GK, McGoon DC, Mair DD. Modified Fontan operation for univentricular heart and complicated lesions. J THORAC CARDIOVASC Surg 1979;78:831-8.

25. Alboliras ET, Julsrud PR, Danielson GK, et al. Definitive operation for pulmonary atresia with intact ventricular septum: results in twenty patients. J THORAC Cardiovasc Surg 1987;93:454-64.

26. Castaneda AR. From Glenn to Fontan: a continuing evolution. Circulation 1992;86(Suppl):II82-3.

27. Laks H, Pearl JM, Haas GS, et al. Partial Fontan: advantages of an adjustable interatrial communication. Ann Thorac Surg 1991;52:1084-95.

28. Hopkins RA, Armstrong BE, Serwer GA, Peterson RJ, Oldham HN, Durham NC. Physiological rationale for a bidirectional cavopulmonary shunt. J THORAC CARDIOVASC SURG 1985;90:391-8.

29. Douville EC, Sade RM, Fyfe DA. Hemi-Fontan operation for single ventricle: a preliminary report. Ann Thorac Surg 1991;51:893-900.

30. Giannico S, Corno A, Marino B, et al. Total extracardiac right heart bypass. Circulation 1992;86(Suppl) II110-7.

31. Fontan F, Fernandez G, Costa F, et al. The size of the pulmonary arteries and the results of the Fontan operation. J Thorac CARDIOVASC SuRg 1989;98:711-24.

32. Nakazawa $M$, Katayama $H$, Imai $Y$, et al. A quantitative analysis of hemodynamic effects of the right ventricle included in the circulation of the Fontan procedure. Circulation 1991;83:822-6.

33. Nakazawa M, Nakanishi T, Okuda H, et al. Dynamics of right heart flow in patients after Fontan procedure. Circulation 1984;69:306-12.

34. DiSessa TG, Child JS, Perloff KJ, et al. Systemic venous and pulmonary arterial flow patterns after Fontan's procedure for tricuspid atresia or single ventricle. Circulation 1984;70:898-902.
35. Akagi T, Benson LN, Green M, Gilday DL, Freedom RM. Diastolic function pre and post Fontan's repair for univentricular heart [Abstract]. J Am Coll Cardiol 1991;17:34A.

36. Gewillig MH, Lundstrom UR, Bull C, Wyse RKH, Deanfield JE. Exercise responses in patients with congenital heart disease after Fontan repair: patterns and determinants of performance. J Am Coll Cardiol 1990;15:1424-32.

37. Driscoll DJ, Danielson GK, Puga FJ, Schaff HV, Heise CT, Staats BA. Exercise tolerance and cardiorespiratory response to exercise after the Fontan operation for tricuspid atresia or functional single ventricle. J Am Coll Cardiol 1986;7:1087-94.

38. Lamberti JJ, Mainwaring RD, Waldman JD, et al. The Damus-Fontan procedure. Ann Thorac Surg 1991;52:676-79.

39. Sade RM, Wiles HB. Pleuroperitoneal shunt for persistent pleural drainage after Fontan procedure. J Thorac CaRdiovasc SuRg 1990;100:621-3.

40. Ponn RB, Blancaflor J, D'Agostino RS, Kiernan ME, Toole AL, Stern H. Pleuroperitoneal shunting for intractable pleural effusions. Ann Thorac Surg 1991; 51:605-9.

41. Fontan F, Kirklin JW, Fernandez G, et al. Outcome after a "perfect" Fontan operation. Circulation 1990; 81:1520-36.

42. Kirklin JK, Blackstone EH, Kirklin JW, et al. The Fontan operation: ventricular hypertrophy, age, and date of operation as risk factors. J THORAC CARDioVASC SURG 1986;92:1049-64.

43. Gewillig M, Wyse RK, de Leval MR, Deanfield JE. Early and late arrhythmias after the Fontan operation: predisposing factors and clinical consequences. Br Heart J 1992;67:72-9.

44. Rothman A, Snyder J. Protein-losing enteropathy following the Fontan operation: resolution with prednisone therapy. Am Heart J 1991;121:618-9.

45. Rychik J, Piccoli DA, Barber G. Usefulness of corticosteroid therapy for protein-losing enteropathy after the Fontan procedure. Am J Cardiol 1991;68:819-21.

46. Hess J, Kruizinga K, Bijleveld C, Hardjowizuvo R, Eygelsaw A. Protein-losing enteropathy after Fontan operation. J Thorac Cardiovasc Surg 1984;88:606-9.

47. Kirklin JW. Fontan operation in infancy [Editorial comment]. J Am Coll Cardiol 1992;19:834. 